\title{
PENGUATAN PAHAM PURITAN DALAM PROGRAM LATIHAN KHIDMAH JAMIYYAH ORGANISASI PERSATUAN ISLAM DI GARUT
}

\author{
Ihsan Kamaludin ${ }^{1}$, Shifa Nisrina Sujana ${ }^{2}$, Afifatus Sholikha ${ }^{3}$ \\ ${ }^{1}$ Center for Religious and Cross-cultural Studies (CRCS), UGM, Yogyakarya, Indonesia, e-mail: ihsankamal95@mail.ugm.ac.id \\ ${ }^{2} M A$ Persis Tarogong, West Java, Indonesia, e-mail:n.shifas123@gmail.com \\ ${ }^{3}$ Dirasat Islamiyyah UIN Syarief Hidayatullah Jakarta, Indonesia, e-mail: afifatus.sholikba16@uinjkt.ac.id
}

\section{(c) (i) (2)}

(C)2020 by the authors. Submitted for possible open access publication under the terms and conditions of the Creative Commons Attribution-ShareAlike 4.0 International License-(CC-BY-SA) (https://creativecommons.org/licenses/by-sa/4.0/)

doi DOI : http://dx.doi.org/10.30983/it.v4i2.3436

Diterima: 31 Agustus $2020 \quad$ Direvisi: 20 Desember $2020 \quad$ Diterbitkan: 31 Desember 2020

\begin{abstract}
This article focuses on implementing the Social learning method, which is used by Persatuan Islam organization in Garut district (West Java) and aims to found the impact of the curriculum for Santri life to strengthen the puritanism among society. This is mainly because Pesantren Persatuan Islam, the Islamic educational institution from Indonesia, has led citizens to broaden their knowledge and skills. Santri (pesantren students) should take a preaching class, which becomes one of the most well-known curriculums to spread Islamic values in society. This is a qualitative-descriptive that uses observation and in-depth interviews. The study indicates the method in Pesantren Persatuan Islam Garut district has a huge impact on social skills since it can also implement in society. This is mainly because the strategies of the Persatuan Islam (Persis) organization give some social contributions, so the people become accustomed to the Persis activities and leading some members of society to enroll their children to some Persatuan Islam religious schools.
\end{abstract}

Keywords: Pesantren; Persatuan Islam; Preaching; Strengthen puritanism.

\begin{abstract}
Abstrak
Artikel ini berfokus pada implementasi dari metode pembelajaran sosial yang diberlakukan oleh organisasi Persatuan Islam di Kabupaten Garut (Jawa Barat) dan bertujuan untuk menemukan dampak dari kurikulum pada kehidupan santri dalam rangka penguatan nilai purtan di masyarakat. Hal ini didasarkan pada Pesantren Persatuan Islam sebagai salah salah satu Lembaga Pendidikan Islam dari Indonesia telah membina masyarakat untuk dapat memperluas ilmu pengetahuan dan keahliannya. Santri (siswa pesantren) harus mendalami dakwah yang menjadi salah satu kurikulum paling populer sehingga mereka mampu untuk menyebarluaskan ajaran Islam puritan di kalangan masyarakat. Penelitian ini menggunakan metode kualitatif deskriptif dan teknik observasi serta wawancara kepada beberapa sumber penting yang berkaitan. Hasil dari penelitian ini menunjukan bahwa metode yang digunakan oleh Persatuan Islam Kab. Garut memberikan dampak yang besar pada kemampuan sosial sejak hal tersebut dapat diimplementasikan di dalam masyarakat. Hal ini disebabkan karena strategi yang digunakan oleh Persis memberikan kontribusi sosial sehingga orang-orang menjadi terbiasa dengan kegiatan Persis serta membuat masyarakat tertarik untuk mendaftarkan anak-anak mereka ke beberapa pesantren Persatuan Islam.
\end{abstract}

Kata Kunci: Pesantren; Persatuan Islam; Dakwah; Penguatan nilai puritan.

\section{Latar Belakang}

Penyebaran paham agama merupakan salah satu hal yang fundamental di kalangan umat Islam. Hal ini dikarenakan doktrin sosial yang diturunkan secara turun temurun bahwa agama Islam haruslah tersebar ke berbagai wilayah karena Islam dianggap sebagai berkah untuk seluruh manusia. Namun, saat ini banyak kelompok agama Islam yang mengalami berbagai perpecahan dan permasalahan dengan berbagai pihak, baik itu sesama muslim ataupun dengan kelompok lain.

Hal tersebut menyebabkan setiap pemuka kelompok keagamaan dan pengikutnya berusaha untuk memenangkan kontestasi sosial yang dimulai dari ideologi keagamaan hingga gerakan perubahan yang berlandaskan pada kepercayaan kelompok mereka. Pemahaman puritan yang dibawa oleh organisasi 
Muhammadiyyah dan Persatuan Islam (Persis) sering kali mengalami perbedaan paham dengan kelompok Islam tradisionalis.

Kehadiran kelompok puritan yang berusaha menumpas berbagai penggabungan nilai agama dan budaya tersebut tentu bertolak belakang dengan visi yang dimiliki oleh kelompok tradisionalis. Meskipun saat ini konflik yang bersifat fisik sudah sangat jarang terjadi, namun kompetisi pengimplementasian nilai-nilai keagamaan yang dilakukan oleh kelompok tersebut masih sering dilakukan sampai saat ini.

Hal yang dapat disaksikan oleh masyarakat yaitu pendirian berbagai lembaga pendidikan serta institusi penyerta lainnya dengan tujuan untuk melanggengkan paham keagamaan mereka di kalangan masyarakat. Hal ini pun dilakukan sebagai bentuk strategi penyebarluasan kepercayaan yang bisa dilakukan oleh peserta didik mereka ketika kembali ke kampung halamanya.

Strategi tersebut juga dilakukan di wilayah Jawa Barat yang menjadi salah satu provinsi terpadat di Indonesia khususnya Organisasi Persatuan Islam yang memiliki pusat basis kepemimpinan di daerah Bandung. Kab. Garut pun yang berlokasi dekat dengan Bandung menjadi pendiri pesantren Persis terbanyak dan berfungsi sebagai basis reproduksi paham keagamaan yang dilakukan kepada para santri atau peserta didiknya.

Organisasi Persatuan Islam (Persis) sendiri awalnya didirikan pada 12 September 1923 di

1 Thomas J O'Shaughnessy, "Indonesian Islamic Reform. Review Islam and Ideology in the Emerging Indonesian State; The Persatuan Islam (PERSIS), 1923 to 1957 by Howard M. Federspiel," Philippine Studies 19, no. 4 (1971): 740.

2 Howard M Federspiel, Islam and Ideology in the Emerging Indonesian State: The Persatuan Islam (Persis) $1923-$ 1957 (Leiden: Brill, 2001), 50-51.

3 Martin van Bruinessen, "Review Islam and Ideology in the Emerging Indonesian State; The Persatuan Islam (PERSIS), 1923 to 1957 by Howard M. Federspiel," International Journal of Middle East Studies 35, no. 1 (2003): 171.
Kota Bandung. ${ }^{1}$ Pada awalnya Organisasi Persis hanyalah kumpulan orang-orang yang mengkaji ilmu agama di masjid dan rumah anggota pengajian. Kajian yang dilakukan oleh organisasi Persis merupakan Gerakan penyatuan pandangan tentang pemisahan antara nilai agama dan budaya. ${ }^{2}$ Kajian tersebut membahas dan mengambil suatu keputusan dari hasil perbandingan hukum keagamaan diantara para ulama imam madzhab dan bertujuan untuk menumpas segala bid'ah, khurafat, dan tahayul. ${ }^{3}$

Dakwah Persis selanjutnya tidak hanya menggunakan media tatap muka seperti diskusi di pengajian dan pertemuan tapi berlanjut ke dalam tahap pembentukan Lembaga formal. Pada tanggal 4 maret 1936, Persis mendirikan Pesantren yang diharapkan dapat menjadi media sosialisasi paham keagamaan. ${ }^{4}$ Persis juga menggunakan media cetak seperti tulisan di artikel dan jurnal ilmiah serta majalah seperti Pembela Islam (1935), At-Taqwa (1937), AlHikam (1939), Aliran Islam (1948) Iber (bahasa sunda), dan Ar-Risalah (1962). ${ }^{5}$

Sampai saat ini, penelitian terkait Pesantren Persatuan Islam sudah banyak dilakukan beberapa peneliti, diantaranya adalah Howard M. Fiderspiel ${ }^{6}$ yang membahas terkait sejarah dan pola Gerakan pemurnian nilai keagamaan yang dilakukan oleh Organisasi Persatuan Islam. Tulisan selanjutnya dibuat oleh Ahmad Anshari $^{7}$ yang berfokus kepada metode Pendidikan pimpinan umum Persatuan Islam yaitu K.H. Aceng Zakaria juga terobosanterobosan yang ia lakukan terkait modifikasi

4 Toto Suharto, Organic Community-Based Education Pesantren Persatuan Islam 1983-1997 (Surakarta: Fataba Press, 2015), 125.

5 Pimpinan Pusat, Pimpinan Pusat Persatuan Islam. Qanun Asasi Qanun Dakhili (Bandung: Pimpinan Pusat Persatuan Islam (Persis), 2015), 212.

6 Federspiel, Islam and Ideology in the Emerging Indonesian State: The Persatuan Islam (Persis) 1923-1957.

7 Ahmad Anshari, Pendidikan Salafi Progresif: Studi Atas Pemikiran Pendidikan Islam K.H Aceng Zakaria Pada Jam'iyyah Persatuan Islam (Jakarta: UIN Syarif Hidayatullah, 2008), 15. 
sistem pembelajaran para peserta didik. Budaya penulisan materi keagamaan tersebut sebenarnya dilakukan sejak dulu, seperti yang dikemukakan dalam penelitian Feener ${ }^{8}$, Kahin ${ }^{9}$, dan Akh. Minhaji ${ }^{10}$ yang menyebutkan bahwa tradisi keilmuan dan literasi keagamaan diawali oleh guru utama Persis yaitu Ahmad Hassan dan M. Natsir yang memproduksi berbagai artikel untuk disebarkan kepada masyarakat. ${ }^{11}$

Abdul Latief Muchtar ${ }^{12}$ selaku demisioner Ketua Umum Persis pun menegaskan dalam bukunya bahwa Persis mengalami pertumbuhan jumlah anggota sejak didirikan karena beberapa pihak menyukai cara dan strategi Persis untuk menghilangkan berbagai percampuran nilai agama dan budaya. Hal tersebut dikuatkan oleh Toto Suharto ${ }^{13}$ dan Hamid Hamdani ${ }^{14}$ yang menjelaskan tentang cara Persis untuk terus memodifikasi bahan ajar serta pola komunikasi dengan masyarakat.

Penelitian yang telah dilakukan oleh beberapa penulis tersebut lebih berfokus kepada peran dari struktur dan kebijakan yang telah disahkan oleh pimpinan Persis. Penelitian kali ini lebih berfokus dalam menganalisis pola serta strategi Organisasi Persatuan Islam Kabupaten Garut dalam menguatkan nilai-nilai puritan di kalangan masyarakat sehingga menjadikan Garut sebagai basis massa terbesar yang dimiliki oleh Persis.

8 R. Michael Feener, Muslim Legal Thought in Modern Indonesia (New York: Cambridge University Press, 2007), 45.

9 Audrey R Kahin, Islam, Nationalism and Democracy: A Political Biography of Mohammad Natsir (Singapore: NUS press, 2012), 32.

${ }^{10}$ Akh Minhaji, "Islamic Reform in Contest: Ahmad Hassan and His Traditionalist Opponents," Studia Islamika 7, no. 2 (2000): 3.

11 Minhaji, "Islamic Reform in Contest: Ahmad Hassan and His Traditionalist Opponents," 87.; Muhamad Ridwan Nurrohman, "Pemikiran Hadis di Nusantara; Antara Tekstualitas dan Kontekstualitas Pemikiran Hadis Ahmad Hassan," Diroyah: Jurnal Ilmu Hadis 2, no. 1 (2017): 24.

12 Abdul Latief Muchtar, Gerakan Kembali ke Islam: Warisan Terakbir K.H A. Latief Muchtar (Bandung: Remaja Rosdakarya, 1998), 76.
Peneliti menggunakan penggalian informasi dengan metode kualitatif deskriptif dengan melakukan berbagai upaya dalam penggalian dan analisa hasil temuan dengan cara melakukan observasi kepada beberapa tempat pusat aktifitas mereka seperti Pesantren Persis Bentar, Tarogong, dan Rancabango serta tempat penting lainnya. Penulis menelusuri berbagai informasi sejarah terkait perkembangan organisasi Persatuan Islam Kab. Garut serta implementasi program pembelajaran praktik pada para peserta didik dengan cara wawancara kepada beberapa tokoh penerus kepemimpinan Persatuan Islam Kab. Garut dengan menggunakan teknik snowball interview (mencari sumber informasi atau narasumber dari narasumber lain) dan mengikuti setiap kegiatan yang dilakukan oleh peserta didik tersebut dalam program praktik pembelajaran lapangan juga kegiatan sosial lainnya. Penulis fokus kepada beberapa pimpinan Pesantren Persis yaitu PPI Bentar, Rancabogo, Rancabango dan Leles serta sekolah Tinggi Persis.

Analisis teoritis yang digunakan di dalam penelitian ini berlandaskan kepada teori Robert K. Merton yang membahas terkait fungsi individu di dalam masyarakat ${ }^{15}$ dalam pola kehidupan sosial. ${ }^{16}$ Fungsi ini dibagi kepada fungsi manifes (sesuatu yang direncanakan dalam gerakan sosial) ${ }^{17}$ serta fungsi laten

\footnotetext{
13 Suharto, Organic Community-Based Education Pesantren Persatuan Islam 1983-1997, 125.

${ }^{14}$ Hamdani Hamid, "Persatuan Islam dan Usaha Berpijak di Bumi Indonesia: Perubahan Kurikulum dalam Pendidikan Pesantren" (UIN Syarief Hidayatullah Jakarta, 1989), 9.

15 Philippe Bezes, "Seeing Public Bureaucracies Like a Sociologist: (A Plea Towards) Reconnecting Sociology and Public Administration," in European Perspectives for Public Administration (Belgium: Leuven University Press, n.d.), 165

${ }^{16}$ Charles Crothers, "Merton as a General Theorist: Structures, Choices, Mechanisms, and Consequences," Springer 35, no. 3 (2004): 28.

17 Ida Zahara Adibah, "Struktural Fungsional Robert K. Merton,” Inspirasi 1, no. 1 (2017).
} 
(sesuatu yang didapatkan walau tidak direncanakan dalam aktifitas tertentu). ${ }^{18}$ Kedua fungsi tersebut penulis gunakan untuk menganalisa metode pengajaran praktik di dalam masyarakat khususnya terkait implementasi tujuan sosial ${ }^{19}$ dan diferensiasi sosial $^{20}$ dalam kelompok keagamaan Persis.

Dengan demikian, penelitian ini fokus kepada faktor yang memengaruhi implementasi nilai puritan di kalangan santri Persis Garut dan bagaimana praktik program Khidmah jamiyah tersebut dapat memengaruhi masyarakat untuk bergabung ke dalam organisasi Persatuan Islam. Hal ini dikarenakan program tersebut menjadi sistem pengajaran yang paling dikenal di kalangan masyarakat dan menjadi ciri khas dari sistem pembelajaran Persis. Apalagi Persis Garut memberikan sumbangsih besar terhadap pengembangan nilai puritan di Jawa Barat sejak santri dan pimpinan Pesantren Persis Garut dapat menduduki posisi sentral di pimpinan pusat organisasi Persis.

\section{Persis dan Paham Puritan}

Organisasi Persatuan Islam dari mulai pembentukannya terus berupaya untuk melakukan berbagai upaya pemurnian nilai keagamaan Islam ${ }^{21}$. hal ini dikarenakan pemahaman mereka yang memandang bahwa masyarakat haruslah kembali kepada nilai-nilai Al-Quran dan Sunnah serta tidak mencampurkan aspek budaya kepada peribadatan yang dilakukan ${ }^{22}$.

18 Piotr Sztompka, Robert K. Merton: Intellectual Profile (London: MacMillan Education, 1986), 14.

19 Gary Dean Jaworski, “Robert K. Merton's Extension of Simmel's Ubersehbar," Sociological Theory 8, no. 1 (1990): 100.

20 Sinisa Malasevic, The Sociology of Ethnicity (India: sage publications, 2004), 46.

21 Muhammad Nur, "Problem Terminologi Moderat dan Puritan dalam Pemikiran Khaled Abou ElFadl," Kalimab: Jurnal Studi Agama dan Pemikiran Islam Problem 11, no. 1 (2013): 94.

${ }^{22}$ Choirunniswah, "Organisasi Islam dan Perannya Terhadap Pendidikan Islam di Indonesia," Jurnal Ta'dib 18, no. 01 (2013): 66
Dasar dari gerakan puritanisme tersebut dikarenakan Persis melihat kondisi masyarakat yang dirasa telah banyak melakukan penyimpangan terhadap nilai-nilai keislaman baik dalam segi ibadah maupun kehidupan hariannya ${ }^{23}$. Persis pun fokus kepada upaya yang merubah atau bahkan mendekonstruksi berbagai kegiatan sosial yang dikategorikan kepada kelompok TBC yaitu Takhayul (hal yang supranatural namun tidak berhubungan dengan nilai keagamaan), bid'ah (praktik yang tidak diajarkan oleh agama dan nabi terutama dalam bidang agama) ${ }^{24}$, dan kburafat (keyakinan pada sesuatu yang tidak sesuai nilai-nilai keislaman). Persis meyakini bahwa salah satu alasan TBC terus terjadi di dalam masyarakat karena hadirnya sikap pengistimewaan yang berlebih kepada pemuka agama Islam tradisionalis yang akhirnya membuat masyarakat muslim melakukan praktik yang tidak ada panduan keagamaannya ${ }^{25}$.

Selain melawan praktik TBC, Persis pun gencar melakukan kritik bahkan gerakan perlawanan tentang paham sekularisme karena dianggap sebagai bentuk pengrusakan terhadap nilai-nilai keagamaan yang seharusnya bersifat holistik ${ }^{26}$. Persis meyakini bahwa nilai-nilai keagamaan Islam harus dipraktikan ke dalam berbagai aspek kehidupan dan tidak boleh ditinggalkan satu pun seperti yang diwacanakan oleh pegiat sekularisme. Oleh karena itu, Persis pun melakukan berbagai upaya sebagai bentuk konkrit dalam melawan berbagai paham dan

23 M. Arfan Mu'ammar, "Pesantren dan Islam Puritan: Pelembagaan Tajdid Keagamaan di Lembaga Pendidikan Islam," Jurnal Peradaban Islam 11, no. 2 (2015): 288.

24 Ahmd Syarif Hidayatullah, "Eksistensi Islam Kultural di Tengah Gempuran Gerakan Islam Transnasional," Jurnal Ilmu Agama 19, no. 1 (2018): 39.

25 Rokhmadi, "Rekonstruksi Ijtihad dalam Ilmu Usul Al-Fiqh," Jurnal Pemikiran Hukum Islam 22, no. 2 (2012): 162 .

26 Fadlurrahman Ashidqi, "Problem Doktrin Sekulerisme," Jurnal Kalimah 12, no. 2 (2014): 216. 
juga fenomena yang tidak direspon berdasarkan nilai-nilai keislaman yang dianggap benar oleh Persis.

Persis pun mendirikan Pesantren di berbagai daerah, saat ini sudah tercatat lebih dari 200 pesantren yang didirikan oleh Persis dan diharapkan mampu untuk melawan bahkan menumpas berbagai praktik yang dianggap sesat oleh Persis. Pesantren-pesantren tersebut pun memiliki misi untuk mereproduksi nilai-nilai puritanisme dan juga memperbanyak sumber daya manusia yang mampu menyebarkan paham puritanisme di kalangan masyarakat.

Program yang diusung oleh Pesantren Persis biasanya diatur dan diawasi oleh Pimpinan Pusat agar visi dan misi Persis dapat terus diimplementasikan. Salah satu kegiatan yang menonjol dalam program Persis tersebut adalah Program Latihan Khidmah Jamiyyah (PLKJ) yang mengharuskan para santrinya untuk melakukan berbagai kegiatan sosial dan keagamaan di masyarakat dalam rangka menguatkan nilai puritanisme yang dimiliki oleh para santri juga menyebarkan nilai puritanisme tersebut kepada masyarakat luas.

\section{Dinamika Pendidikan Persis}

Pada awal kemunculannya, Persis menggunakan metode shock therapy dengan mengangkat isu-isu kontroversial dan menggugat kebiasaan-kebiasaan ibadah di masyarakat dengan tujuan untuk mendapatkan perhatian dan juga menyebarkan pemahaman baru yang sering kali bertolak belakang dengan ideologi sebelumnya. ${ }^{27} \mathrm{Hal}$ ini menimbulkan banyak keresehan diantara masyarakat tradisionalis karena Gerakan yang dilakukan oleh Persis sering kali bertolak belakang dengan

27 Robert W Hefner, "Islam and Ideology in the Emerging Indonesian State: The Persatuan Islam (PERSIS), 1923-1957 by Howard M. Federspiel," The Journal of Asian Studies 62, no. 1 (2003): 335.

28Pepen Irfan Fauzan (Anggota Dewan Tafkir Pimpinan Pusat Persis), Wawancara, 10 Maret 2017.

${ }^{29}$ Kakah Mustikah (Ketua Persatuan Islam Istri Kab. Garut), Wawancara, 27 Maret 2017. tradisi mereka. Hal ini pun membuat masyarakat memberikan respon yang berupa berbagai penolakan sosial terhadap kehadiran ormas Persis. ${ }^{28}$ Penolakan keberadaan paham keagamaan Persis pada waktu itu karena Persis banyak mengkritik cara peribadatan masyarakat dan menggunakan teknologi alat bantu seperti pengeras suara padahal masyarakat dari dulu menggunakan bedug dan kohkol (sejenis pemukul yang digunakan untuk pertanda waktu sholat). ${ }^{29}$

Persis pun sering kali mengadakan berbagai kegiatan pengajian dan acara diskusi sosial yang dilakukan secara tatap muka ${ }^{30}$ atau melalui media radio $^{31}$ pada waktu tertentu sehingga memperluas pengajaran keagamaan Persis. Hal ini pun dilakukan oleh pimpinan Persis dengan tujuan agar mendapat dukungan dari para simpatisan gerakan puritan dan mendapatkan legimitasi sosial yang berupa penerimaan kegiatan-kegiatan rutin Persis di kalangan masyarakat.

Meskipun terjadi banyak penolakan, Persis mampu tetap berkembang di masyarakat. Hal ini dikarenakan para anggota Persis aktif di berbagai organisasi masyarakat lain seperti lembaga pemerintahan dan sosial. Bahkan, mereka pun kerap kali turut ikut andil di dalam partai politik khususnya Masyumi. Pepen mengatakan bahwa banyak tokoh Persis yang aktif di Masyumi, jadi pada saat mengembangkan Masyumi, mereka sekaligus mengenalkan pabam keagamaan Persis ke masyarakat. ${ }^{32}$

Metode yang dilakukan oleh aktifis Persis tersebut bertujuan agar masyarakat lebih mudah menerima kehadiran Persis karena mereka membangun retorika dakwah yang menekankan bahwa ideologi Masyumi sejalan dengan

30 Ena Sumpena (Ketua Persis Kab, Garut), Wawancara, 13 Januari 2020.

31 Endut Saefudin (Penasehat PD. Persis Kab. Garut), Wawancara, 23 Maret 2017.

32 Pepen Irfan Fauzan (Anggota Dewan Tafkir Pimpinan Pusat Persis), Wawancara, 12 Maret 2020 
ideologi Persis. Lebih jauh lagi, para aktifis tersebut sering kali ikut aktif dalam berbagai kegiatan masyarakat yang berakibat pada perubahan stigma sosial yang ditujukan pada anggota kelompok organisasi Persatuan Islam. Persis pun mulai diterima oleh banyak orang yang mulai bersimpati pada ideologi mereka.

Dalam rangka penguatan eksistensi organisasi, Persis merubah metode dakwah mereka yang awalnya menggunakan teknik shock therapy menjadi lebih halus dengan cara menunjukan berbagai praktik ibadah Persis kepada masyarakat. Adaptasi ini dilakukan agar masyarakat lebih mudah menerima kehadiran Persis karena tidak mengganggu praktik ibadah kelompok tradisional. Setelah aktifis Persatuan Islam mulai diterima, mereka pun melakukan diskusi perbandingan madzhab agar masyarakat memahami segala bentuk perbedaan praktik ibadah keagamaan yang hadir dan berkembang di wilayahnya. Metode ini pun dipercaya oleh para pimpinan Persis sebagai cara yang mempermudah masyarakat untuk bersimpati juga mendirikan cabang organisasi di berbagai wilayah.

Saat ini Persis memiliki 19 Pimpinan Wilayah (setingkat Provinsi) dan mendirikan lebih dari 200 pesantren di Pulau Jawa. ${ }^{33}$ Iyep mengatakan bahwa program pengabdian kepada masyarakat pun menjadi kurikulum baku di Persis dan mengharuskan santri untuk melakukan praktik pembelajaran lapangan serta membantu memenuhi kebutuhan masyarakat khususnya dalam masalah agama Islam serta pendidika. $^{34}$

Salah satu wilayah penyebaran nilai yang dilakukan oleh organisasi Persis yaitu adalah Kab. Garut. Daerah tersebut merupakan pusat

33 Persatuan Islam, "Sejarah Persatuan Islam," accessed September 10, 2020, https://www.persis.or.id/page/sejarah.

${ }^{34}$ Iyep Komarudin (Mantan Ketua PD Persis Kab. Garut dan Ketua Bidgar Haji), Wawancara, 22 Maret 2017

35 Ena Sumpena (Ketua Persis Kab Garut), Wawancara, 13 Januari 2020.
Pendidikan pesantren Persis karena memiliki jumlah Lembaga terbanyak dari berbagai jenjang. $^{35}$ Pesantren Persatuan Islam di Kabupaten Garut mencapai 35 sekolah untuk jenjang Madrasah Tsanawiyyah (tingkat menengah pertama). Jumlah tersebut terus bertambah seiring dengan pertumbuhan kebutuhan masyarakat akan hadirnya institusi pendidikan berbasis keagamaan.

\section{Metode Pembelajaran Praktik Lapangan Santri Persis}

Program ini sebenarnya adalah hasil dari kebiasaan para ustaz Persis yang pada awalnya sering membawa santri-santri pilihan untuk ikut berdakwah ke beberapa tempat dan masjid. ${ }^{36}$ Santri biasanya ditugaskan untuk memperhatikan cara retorika dakwah hingga belajar untuk berdakwah di depan masyarakat. ${ }^{37}$ Setelah proses pembelajaran dakwah dinilai cukup oleh ustaz yang membimbingnya, santri pun diberikan izin untuk berdakwah bahkan diberikan jadwal tetap untuk mengisi kajian di masjid-masjid. ${ }^{38}$

Program ini pun menjadi suatu tradisi di lingkungan pesantren Persis dan diformalkan ke dalam kurikulum di tiap pesantren khususnya pada jenjang Sekolah Menengah Atas. ${ }^{39} \mathrm{Hal}$ ini bertujuan untuk mengembangkan nilai-nilai puritanisme di dalam masyarakat serta menguatkan nilai-nilai keagamaan Persis di lingkungan santrinya.

Menurut Iqbal Santoso, program ini merupakan suatu budaya aktif dalam pengajaran dan penyebaran paham keagamaan Persis di dalam masyarakat. Ia mengatakan bahwa dalam aturan kurikulum Pesantren Persis sebenarnya hanya bersifat umum, adapun Pesantren lain

\footnotetext{
${ }^{36}$ Dede Sodikin (Penasehat PD. Persis Kab. Garut), Wawancara, 23 Maret 2017

37 Ena Sumpena (Ketua Persis Kab, Garut), Wawancara, 13 Januari 2020.

38 Endut Saefudin (Penasehat PD. Persis Kab. Garut), Wawancara, 23 Maret 2017.

39 Iqbal Santoso (Ketua Dewan Hisab dan Rukyat PP. Persis), Wawancara, 13 Januari 2020.
} 
yang mengajarkan mata pelajaran Bahasa Arab dan praktik sosial yang begitu banyak macamnya hanyalah sebuah kebiasaan. ${ }^{40}$

Program ini dinamakan latihan Khidmat Jam'iyah atau sering disebut sebagai PLKJ (di beberapa sekolah Persis ada yang menggunakan istilah PKKJ/ PKL) yaitu adalah program pengabdian sosial ke dalam masyarakat. ${ }^{41} \mathrm{Hal}$ ini dilakukan pada masa sekolah SMA/ MA/ Muallimien selama empat belas hari sampai dua puluh satu hari (biasanya dilakukan setelah Ujian Nasional namun ada beberapa sekolah yang mengadakan program ini ketika santri berada di kelas sebelas). ${ }^{42}$ Kegiatan yang dilakukan oleh para santri adalah membantu pengembangan masjid dan sekolah serta kegiatan massyarakat lainnya sehingga masyarakat merasa terbantu akan kehadiran dari para santri. ${ }^{43}$

Program ini adalah program wajib dan dilakukan di semua sekolah dan otonom seperti Pemuda-Pemudi Persis, HIMA-HIMI Persis (Himpunan mahasiswa-mahasiswi) dan IPPIPPi (Ikatan pelajar Persis putra-putri) dalam rangka memperkenalkan, menguatkan dan menyebarkan paham keagamaan Persis ke berbagai daerah di wilayah Kab. Garut bahkan kadang dikirim ke beberapa kabupaten lainnya. ${ }^{44}$ Biasanya, Sebelum program ini dilaksanakan, peserta program PLKJ biasanya dibekali oleh mata pelajaran dakwah dan retorika di sekolah juga dikuatkan dengan mata pelajaran adab atau etika sosial yang bersumber dari Al-Qur'an dan hadits. ${ }^{45}$

Pelajaran tersebut biasanya diberikan sejak kelas satu dan guru yang sering kali memberikan tugas berupa praktik lapangan selama seminggu di tempat tinggal santri masing-masing untuk

${ }^{40}$ Iqbal Santoso (Ketua Dewan Hisab dan Rukyat PP. Persis), Wawancara, 25 Maret 2017.

${ }^{41}$ Mamat Abdul Rahman (Mantan Ketua PD. Persis Kab. Garut), Wawancara, 18 Maret 2020.

42 Ena Sumpena (Ketua Persis Kab, Garut), Wawancara, 13 Januari 2020.

43 Iqbal Santoso (Ketua Dewan Hisab dan Rukyat PP. Persis), Wawancara, 25 Maret 2017. dapat berpartisipasi dalam kegiatan mengajar juga sosial lainnya. Beberapa sekolah Persis tersebut juga sering kali mengadakan programprogram praktik bersama agar dapat mengadakan program pengabdian yang lebih besar dan dapat dirasakan oleh masyarakat.

Salah satu sekolah pionir yang telah menyelenggarakan program PLKJ adalah sekolah PPI 99 Rancabango dari tahun 1994. Program ini dilakukan selama tiga minggu setelah Ujian Akhir di luar Kab. Garut dan setiap bulan Ramadhan di wilayah pelosok Kab. Garut. Program PLKJ Ramadhan tersebut, biasanya dilakukan oleh santri kelas sebelas sedangkan untuk PLKJ luar Kab. Garut dilakukan oleh santri kelas dua belas. ${ }^{46}$

Otonom-otonom seperti HIMA-HIMI (mahasiswa Persis dan IPP-IPPi (pelajar) juga melaksanakan program tersebut dalam rangka pengenalan dan pengembangan dakwah otonom Persis. Setiap tahun dilaksanakan PLKJ bagi staf dan anggota untuk bisa membantu masyarakat dalam hal sosial keagamaan. Anggota IPP-IPPI melaksanakan program PLKJ dua minggu pada bulan Ramadhan dan diisi oleh mengajar serta memakmurkan masjid, ada seminar tentang pendidikan juga. ${ }^{47}$

Jika merunut kepada Teori Merton, pengembangan kurikulum yang dilakukan oleh tokoh dan sekolah Persis di Kab. Garut memiliki fungsi manifes yang berupa perencanaan dan pengajaran nilai-nilai Persis di kalangan santri Persis Kab. Garut. Para peserta didik pun diwajibkan untuk melakukan program lapangan pekerjaan tersebut dengan tujuan

${ }^{44}$ Rifqi Rifyal Rizaldi (Ketua Ikatan Pelajar Persis Kab. Garut), Wawancara ,22 Maret 2017.

${ }^{45}$ Luthfi Lukman Hakim (Kepala Sekolah Pesantren Persis Rancabango), Wawancara, 31 Maret 2017.

${ }^{46}$ Luthfi Lukman Hakim (Kepala Sekolah Pesantren Persis Rancabango), Wawancara, 31 Maret 2017.

${ }^{47}$ Azkia Wafiatul Wijdaniah (Bidgar SDMO PD. IPPi Kab. Garut), Wawancara, 22 Maret 2017. 
untuk mengajarkan juga melanggengkan nilai dasar keagamaan. ${ }^{48}$

Pada proses pembekalan nilai dan norma keagamaan di sekolah pun, para santri dilatih secara konsisten untuk dapat berpegang pada prinsip visi dan misi keagamaan Organisasi Persatuan Islam. Hal ini dilakukan agar tidak ada santri yang menggunakan nilai organisasi keagamaan lain seperti kelompok tradisionalis. Program ini juga ditujukan agar santri yang memiliki nilai keagamaan non-Persis dapat memberikan edukasi keagamaan pada keluarga mereka supaya bisa mengikuti aturan dan kebiasaan cara peribadatan orang Persis.

Adapun fungsi laten dari program ini yaitu pihak pesantren dapat memahami kondisi keagamaan di tempat tinggal para santrinya yang nantinya dapat digunakan untuk merancang strategi penyebar luasan paham keagamaan Persis. Santri pun kerap kali tidak sadar bahwa mereka menstimulasi seluruh kegiatan hariannya dengan mengacu pada nilai-nilai Persis yang pada akhirnya sering kali membuat mereka memutuskan suatu masalah dengan sudut pandang paham keagamaan Persis.

Pemangku kebijakan seperti kepala sekolah dan pimpinan daerah pun sering kali berusaha untuk terus bersosialisasi dengan masyarakat non-Persis agar dapat menemukan berbagai informasi terkait kondisi keagamaan mereka. Terlebih lagi, para tokoh Persis kerap kali melakukan berbagai cara yang dapat dimanfaatkan seperti berinteraksi dan melakukan kerja sama dalam kegiatan seharihari dalam rangka mensosialisasikan kepercayaan dan nilai yang dianut oleh Persis ${ }^{49}$

48 Guillermina Jasso, "Some of Robert K. Merton's Contributions to Justice Theory," Sociological Theory 18, no. 2 (2000): 332.

49 Robin DiAngelo, "Socialization," Counterpoints 467 (2016): 27.

50 Tim S. Müller, Peter Schmidt, and Nan Dirk De Graaf, "Which Societies Provide a Strong Religious Socialization Context? Explanations Beyond the Effects of National Religiosity," Journal for the Scientific Study of Religion 53, no. 4 (2014): 740. terutama kepada kolega dan masyarakat di sekitar mereka. ${ }^{50}$

Kegiatan yang dilakukan oleh seluruh elemen ormas Persis tersebut dilakukan untuk memberikan bekal pada para santri agar dapat menjadi seorang role model di dalam masyarakat ${ }^{51}$ serta mampu bersaing di dalam arena sosial yaitu kontestasi paham keagamaan yang terjadi di dalam masyarakat. Arena sosial tersebut menjadi ajang dominasi kepercayaan dan penyebaran hegemoni sosial agar seluruh kegiatan yang dilakukan oleh masyarakat mengacu kepada ajaran ormas keagamaan Persis. $^{52}$

\section{Implementasi Metode Penyebaran Paham Puritan}

Program praktik dakwah yang dilakukan oleh santri sering kali mendapatkan respon positif masyarakat karena dinilai baik untuk melatih siswa dalam meningkatkan kemampuan orasi mereka. ${ }^{53}$ Masyarakat pun menilai bahwa program ini harus dikembangkan agar siswa tidak hanya belajar teori namun juga mampu berkontribusi secara langsung kepada masyarakat. $^{54}$

Program yang dijalankan oleh santri pada hari pertama biasanya berupa silaturahmi atau perkenalan kepada masyarakat dan aparat setempat dengan mendatangi setiap tempat satu-persatu disertai dengan sosialisasi program yang akan di lakukan selama kegiatan berlangsung.

Hal ini dilakukan agar para santri dapat memahami kondisi sosial yang ada di masyarakat tersebut dan melakukan pendekatan

51 Adibah, "Struktural Fungsional Robert K. Merton," 176.

${ }^{52}$ Frédéric Vandenberghe, "The Real Is Relational': An Epistemological Analysis of Pierre Bourdieu's GenerativeStructuralism," Sociological Theory 17, no. 1 (1999): 57.

${ }^{3}$ Daden Robi Rahman (Ketua PD. Pemuda Persis Kab. Garut), Wawancara, 16 Maret 2017.

${ }^{54}$ Mamat Abdul Rahman (Mantan Ketua PD. Persis Kab. Garut), Wawancara, 18 Maret 2020. 
sosial agar dapat diterima di lingkungan tempat praktik dilakukan. Kegiatan silaturahmi kepada aparat atau pejabat setempat pun dilakukan oleh para santri agar mereka dapat menghindari masalah yang mungkin bisa terjadi pada saat program dilaksanakan dikarenakan perbedaan nilai dan norma yang dimiliki oleh santri dan masyarakat. Lebih jauh lagi, santri bisa mendapatkan perlindungan dari tokoh masyarakat tersebut serta menjadi mediator jika memang terdapat kesalahpahaman pada saat para santri melaksanakan program yang sudah dicanangkan di suatu daerah.

Pada hari selanjutnya, peserta program biasanya mulai melakukan beberapa hal yang dibutuhkan di dalam masyarakat seperti mengisi pengajian atau imam dalam shalat serta mengajar di sekolah. Sering kali masyarakat memberikan kesempatan bagi para santri untuk memimpin kegiatan peribadatan karena adanya stigma bahwa santri memiliki wawasan dan keterampilan keagamaan yang dapat digunakan di dalam kehidupan sosial. ${ }^{55}$ Dalam acara pengajian, para santri biasanya membahas terkait adab dan akhlak dan berusaha untuk menunjukan hal tersebut ketika program PLKJ berlangsung. ${ }^{56} \mathrm{Hal}$ ini dilakukan untuk menghindari perselisihan perbedaan cara beribadah karena masyarakat pada umumnya menggunakan pedoman imam Syafi'i. lebih lanjut lagi, bahasan-bahasan tersebut dipilih agar masyarakat bersimpati dan mulai tertarik untuk memasukan anak-anak mereka ke sekolah Persis karena mencerminkan perilaku yang baik.

Sekolah Dasar (SD) dan Menengah Pertama (SMP) di wilayah program PLKJ juga biasanya memberikan kesempatan kepada santri untuk bisa berbagi wawasan ilmu agama islam di dalam jam pelajaran. Bahkan ada beberapa sekolah yang memberikan waktu penuh selama dua minggu pada santri untuk mengajar seluruh

${ }^{55}$ Luthfi Lukman Hakim (Kepala Sekolah Pesantren Persis Rancabango), Wawancara, 31 Maret 2017.

56 Rifqi Rifyal Rizaldi (Ketua Ikatan Pelajar Persis Kab. Garut), Wawancara, 22 Maret 2017. mata pelajaran karena santri dianggap mampu mensinergikan antara ilmu agama dan umum. ${ }^{57}$ Terkadang, santri pun bebas mengajarkan berbagai hal di sekolah agar anak-anak peserta didik mendapatkan keterampilan baru yang tidak didapatkan di dalam kurikulum mata pelajaran SD/SMP.

Pada saat pelaksanaan program, santri diberikan keleluasaan untuk membentuk program kegiatannya sendiri sesuai kebutuhan masyarakat, Pembina pun hanya datang untuk memberikan pengarahan dan melakukan evaluasi agar program yang dijalankan bisa memberikan dampak signifikan terhadap kehidupan masyarakat sekitar. Hal ini dilakukan agar para santri memiliki kemandirian dan kreatifitas untuk bisa hidup bersosial di dalam masyarakat.

Program Latihan Khidmat Jam'iyyah sendiri tidak hanya berfokus pada Pendidikan dan keagamaan saja namun juga sering kali diisi dengan kegiatan sosial yaitu santunan atau pemberian donasi bagi anak yatim atau janda berupa uang dan pakaian serta wakaf al-quran bagi masjid yang membutuhkan. Hal ini dilakukan agar masyarakat tetap mendapatkan manfaat dari program PLKJ walaupun program tersebut telah usai. Di sisi lain, pemberian donasi pun diharapkan membuat santri peserta program sadar bahwa nilai sosial dan kebersamaan harus dijunjung tinggi karena hal tersebut merupakan ajaran dasar dalam Islam khususnya landasan Ormas Persis. ${ }^{58}$

Visi Misi Ormas Persis pun menjadi acuan untuk mengajak dan menyebarkan paham keagamaan Persis khususnya pada kegiatan PLKJ yang sedang dilakukan oleh para santri karena dipercaya sebagai sebuah ajaran Islam yang komprehensif dan mampu merangkul serta membentuk suatu kelompok masyarakat yang sesuai dengan ajaran al-quran dan sunnah.

57 M Shodiq, "Pesantren dan Perubahan Sosial," Falasifa 2, no. 2 (2011): 112.

58 Daden Robi Rahman (Ketua PD. Pemuda Persis Kab. Garut), Wawancara, 16 Maret 2017. 
Maka dari itu, pembimbing biasanya memberikan pembekalan kepada santrinya pada saat sebelum acara dilaksanakan hingga kegiatan selesai. Penguatan nilai-nilai keagamaan Persis pun sering kali dibantu oleh otonom Persis lainnya melalui kegiatan berkelanjutan dengan melibatkan para santri yang pernah melakukan program PLKJ di tempat tersebut.

Otonom-Otonom Persis pun terkadang menyelenggarakan kegiatan yang serupa dengan PLKJ karena meyakini bahwa ajaran Islam tidak cukup jika hanya disebarkan melalui program sekolah namun harus dilanjutkan oleh lembaga eksternal sekolah. Hal ini dilakukan agar suatu nilai yang sudah hadir di dalam masyarakat bisa dikuatkan dan disebarkan ke lingkungan daerah tersebut. ${ }^{59}$

Persis pun di tataran kampusnya mewajibkan mahasiswa jurusan ilmu hadis untuk melakukan program pengabdian selama satu tahun ke luar pulau Jawa sebagai salah satu syarat kelulusan dari kampus. $^{60}$ Hal ini dilakukan agar ilmu yang didapatkan dari perguruan tinggi benar-benar dapat dimanfaatkan dengan baik di masyarakat. Biasanya mahasiswa tersebut harus mengisi acara rutin di masjid dan desa tertentu hingga dapat membuahkan suatu kegiatan keagamaan tertentu bahkan agar masyarakat memiliki paham keagamaan Persis (walaupun hal ini tidak wajib).

Meskipun mayoritas masyarakat biasanya menerima program tersebut, namun ada beberapa kasus penolakan kehadiran santri Persis di suatu lingkungan. Hal ini terjadi karena beberapa anggota masyarakat tidak menginginkan paham keagamaan Persis hadir

${ }^{59}$ Rifqi Rifyal Rizaldi (Ketua Ikatan Pelajar Persis Kab. Garut), Wawancara, 22 Maret 2017.

60 Gungun Abdul Basith (dosen STAI-Persis Garut), Wawancara, 28 Maret 2017.

61 Federspiel, Islam and Ideology in the Emerging Indonesian State: The Persatuan Islam (Persis) 1923-1957; Howard M Federspiel, The Muhammadijah: A Study of an Orthodox Islamic Movement in Indonesia. Indonesia (New York: dan mengganggu paham keagamaan masyarakat tradisionalis yang mayoritas merujuk pada ajaran imam Syafi'i. Bentuk penolakan tersebut berupa diskusi pemikiran antara paham keagamaan hingga pengusiran yang dilakukan secara dialog (tanpa ada kekerasan). Penolakan tersebut pun direspon oleh sekolah Persis dengan cara berpindah ke tempat lain yang siap menampung mereka.

Program kegiatan PLKJ di tataran pelajar dan mahasiswa yang dilakukan oleh ormas Persatuan Islam tersebut memberikan gambaran sosial bagi masyarakat terkait strategi dan upaya kelompok keagamaan puritan dalam rangka meraih tujuan yang ingin dicapai yaitu penyebaran paham keagamaan puritan. ${ }^{61}$ Lembaga sekolah dan pimpinan daerah berusaha meramu berbagai langkah-langkah efektif untuk membuat santri dapat beradaptasi dan memiliki peran sentral di dalam kegiatan sosial.

Merton berpendapat bahwa upaya sistematis agar dapat mencapai tujuan tersebut juga meminimalisir kemungkinan terjadinya disfungsi sosial ketika program dijalankan. ${ }^{62}$ Oleh sebab itu Persis melakukan berbagai upaya yang dirasa bermanfaat ketika program berjalan. ${ }^{63}$

Menurut kepada teori Merton tentang arena dan agen sosial, pelaksanaan kegiatankegiatan sosial berbasis keagamaan yang dilaksanakan oleh para santri mengacu pada cara adaptasi sosial agar masyarakat tidak memberikan penolakan terhadap kehadiran mereka.$^{64}$ Kegiatan yang sistematis pun biasanya akan menghasilkan suatu penerimaan paham keagamaan Persis dan pembiasaan kegiatan

Southeast Asia Program Publications at Cornell University, 1970).

${ }^{2}$ Kathy S Stoley, The Basic of Sociology (Westport: Greenwood press, 2005), 24.

${ }^{63}$ Gungun Abdul Basith (Dosen STAI-Persis Garut), Wawancara, 28 Maret 2017.

64 Charles H. Page, "Bureaucracy and Higher Education," The Journal of General Education 5, no. 2 (1951): 93. 
ormas Persis diantara masyarakat sehingga mereka tidak akan tersinggung jika ada suatu nilai ibadah yang mulai dirubah (tidak terjadi disfungsi sosial ketika nilai keagamaan masyarakat sengaja diubah). ${ }^{65}$

Pada saat pelaksanaan kegiatan PLKJ di setiap jenjang, Pimpinan Persis Kab. Garut juga melakukan monitoring kegiatan. Hal ini dilakukan oleh mereka agar persiapan penyebaran hingga evaluasi dan langkah lanjutan dapat dilaksanakan. Biasanya ketika program PLKJ akan dilaksanakan, tokoh Persis melakukan konsolidasi kepada pimpinan Persis di daerah tersebut atau minimal mencari simpatisan agar memiliki pihak pendukung acara di tempat yang akan dituju.

Langkah selanjutnya yang biasanya dilakukan adalah pengenalan program terhadap tokoh masyarakat di sana yang mengedepankan aktifitas sosial berbasis keagamaan agar mendapat simpati dari masyarakat dan diharapkan segala jenis kegiatan yang akan dilakukan dapat berjalan dengan baik. Tokoh Persis tersebut akan meminta bantuan pada tokoh lokal agar proses sosialisasi dapat berjalan dengan baik. Ketika program dilaksanakan, pihak pesantren memanglah yang memiliki peran aktif dalam berinteraksi dengan masyarakat, namun setiap jenis kegiatan dilaporkan kepada pimpinan daerah.

Informasi yang diberikan oleh pihak pesantren pun akan digunakan untuk program penyebaran paham puritan secara berkelanjutan dengan kegiatan-kegiatan keagamaan seperti penjadwalan pengajian bulanan yang akan dipandu oleh tokoh Persis. Selain itu, biasanya Persis pun akan berusaha terlibat ke dalam acara kemasyarakatan agar menunjukan eksistensi dari ajaran dan juga kepedulian sosial mereka.

${ }^{65}$ Jerome C. Manis, Bernard N. Meltzer, and Jerome G. Manis, "Blumer And Merton: Social Roles And Sociological Theories," Sociological Focus 7, no. 4 (1974): 9.

\section{Evaluasi Sistem Pembelajaran Praktik Persis}

Santri Persis dan otonom yang terlibat dalam kegiatan Pelatihan Khidmat Jam'iyyah (PLKJ) juga sering kali melakukan aksi bakti sosial lain seperti aksi kemanusiaan bagi masyarakat dunia seperti Palestina dan Rohingya dengan cara orasi di dalam kegiatan pengajian atau diskusi hingga mengumpulkan donasi untuk bisa dikirimkan ke negara yang membutuhkan. Hal tersebut merupakan manifestasi sosial organisasi Persis yang bertujuan untuk membantu sesama muslim di seluruh dunia. Kegiatan tersebut biasanya dilakukan ketika suatu kasus muncul di media atau ketika acara PLKJ telah hampir selesai. Bantuan pun sering diberikan juga kepada masyarakat lokal atau keluarga ormas Persis yang sedang mengalami kesulitan.

Hal ini menjadi salah satu penarik simpati masyarakat dimana ketika masyarakat khususnya keluarga anggota dan simpatisan Persis berada dalam kesulitan, Persis hadir membantu menyelesaikan permasalahan tersebut. Kegiatan-kegiatan bantuan kemanusiaan membuat masyarakat berinteraksi langsung dengan anggota dan tokoh Persis serta menimbulkan hubungan keterkaitan atau kerap kali membuat masyarakat awam lebih ingin mengetahui kegiatan-kegiatan dan paham keagamaan Persis.

Proses sosialisasi ajaran Persis melalui santri dalam program PLKJ dan aksi sosial lainnya diakui oleh sebagaian masyarakat sebagai suatu moment pengenalan ajaran yang berbeda dari paham keagamaan tradisionalis dan juga di beberapa tempat ada yang meminta untuk menjadi tujuan program PLKJ rutin setiap tahun. ${ }^{66}$ Para santri yang dinilai cakap pun sering kali diminta untuk menetap dan memberi wawasan keagamaan di suatu daerah. Hal ini

${ }^{66}$ Luthfi Lukman Hakim (Kepala Sekolah Pesantren Persis Rancabango), Wawancara, 31 Maret 2017. 
diakui oleh ketua PD. Persis Kab. Garut sebagai suatu dorongan untuk terus melahirkan anggota Persis yang baru bahkan pimpinan cabang yang baru. ${ }^{67}$

Kegiatan PLKJ yang dilakukan oleh para santri tersebut memberikan pengaruh yang signifikan dalam penyebaran paham keagamaan Persis di kabupaten Garut. Saat ini, Kabupaten Garut menjadi daerah yang memiliki sekolah terbanyak dibandingkan dengan daerah lainnya, jumlahnya sekitar tiga puluh enam Pesantren di berbagai jenjang pendidikan dan satu Sekolah Tinggi. ${ }^{68}$ Persis pun menargetkan pendirian pesantren di Kab. Garut setidaknya dua pesantren setiap tahunnya karena jumlah sekolah pesantren di Kab. Garut masih sedikit dibanding jumlah penduduk dan luas Kab. Garut. Ena berpendapat bahwa kebutuhan umat masih banyak terhadap pesantren Persis di Kab. Garut. ${ }^{69}$

Masyarakat dari beberapa tempat yang pernah mendapatkan bantuan dari organisasi dan santri Persis pun sering kali tertarik untuk memasukan anaknya ke sekolah Persis karena melihat santri bukan hanya aktif secara akademik namun juga sosial kemasyarakatan. Pimpinan Persis pun sampai saat ini berusaha untuk memperbaharui kurikulum dan sistem pengajaran agar lebih dapat dirasakan oleh masyarakat luas. Hal ini juga dimanfaatkan oleh pimpinan Persis sebagai suatu sarana penyebaran paham keagamaan dan pendirian lembaga keilmuan Persis ketika para santri kembali ke kampung halamannya.

Meskipun mayoritas masyarakat merespon kegiatan PLKJ sebagai suatu ajang latihan santri untuk menunjukan eksistensi keilmuan dan juga keterampilan yang dimiliki. Namun kasus penolakan kehadiran santri di kalangan sebagian masyarakat menjadi suatu bukti adanya kontestasi nilai keagamaan diantara penganut paham puritan dan tradisional. Tempat praktik lapangan PLKJ pun menjadi suatu arena yang menjadi tempat perebutan dominasi dua paham keagamaan yang saling bertentangan. ${ }^{70}$

Hal ini pun menjadi perhatian para tokoh Persis serta menganggap bahwa hal tersebut merupakan sebuah disfungsi sosial yang harus segera diperbaiki agar penyebaran paham keagamaan dapat berjalan dengan baik. Para tokoh tersebut pun akhirnya membentuk suatu role model atau seorang yang dianggap dapat mengayomi dan mengajak masyarakat untuk bisa bergabung ke dalam kegiatan ormas Persis. $^{71}$

\section{Kesimpulan}

Penguatan nilai puritan di kalangan santri di Kab. Garut telah memberikan dampak signifikan terkait peningkatan jumlah santri Persis di beberapa pesantren dan juga pendirian pimpinan cabang di tingkat kecamatan hingga perkampungan pun semakin bertambah dikarenakan hadirnya penambahan jumlah anggota. Hal ini berkaitan erat dengan program PLKJ yang terus dilakukan oleh sekolahsekolah Persis.

Kegiatan-kegiatan yang dirancang oleh tokoh Persis Kab. Garut tersebut juga dapat menjadi gambaran terkait masifnya penyebaran keagamaan puritan di kalangan masyarakat sehingga dapat merubah pola pikir ibadah mereka khususnya terkait pola ibadah yang dianggap Persis sesuai dengan tuntunan ajaran agama. Lebih lanjut lagi, kegiatan santri biasanya tidak terbatas pada saat PLKJ namun juga dilanjutkan dengan kegiatan amal supaya relasi

${ }^{70}$ Stephen W. Foster, "Reading Pierre Bourdieu," Cultural Anthropology 1, no. 1 (1986): 105.

71 Crothers, "Merton as a General Theorist: Structures, Choices, Mechanisms, and Consequences," 32.

\footnotetext{
${ }^{67}$ Ena Sumpena (Ketua PD. Persis Kab. Garut), Wawancara, 29 Maret 2017.

68 Ena Sumpena (Ketua Persis Kab, Garut), Wawancara, 13 Januari 2020.

69 Ena Sumpena (Ketua Persis Kab, Garut), Wawancara, 13 Januari 2020.
} 
sosial antara santri dan masyarakat masih bisa ditingkatkan. Hal ini dilakukan agar penyebaran nilai puritan dapat terus berkembang yang diimplementasikan ke dalam pendirian kantor cabang Persis di berbagai wilayah di Kabupaten Garut.

\section{Daftar Kepustakaan}

Adibah, Ida Zahara. "Struktural Fungsional Robert K. Merton.” Inspirasi 1, no. 1 (2017).

Anshari, Ahmad. Pendidikan Salafi Progresif: Studi Atas Pemikiran Pendidikan Islam K.H Aceng Zakaria Pada Jam'iyyah Persatuan Islam. Jakarta: UIN Syarif Hidayatullah, 2008.

Ashidqi, Fadlurrahman. "Problem Doktrin Sekulerisme." Jurnal Kalimah 12, no. 2 (2014): 213-35.

Bezes, Philippe. "Seeing Public Bureaucracies Like a Sociologist: (A Plea Towards) Reconnecting Sociology and Public Administration." In European Perspectives for Public Administration. Belgium: Leuven University Press, n.d.

Bruinessen, Martin van. "Review Islam and Ideology in the Emerging Indonesian State; The Persatuan Islam (PERSIS), 1923 to 1957 by Howard M. Federspiel." International Journal of Middle East Studies 35, no. 1 (2003).

Choirunniswah. "Organisasi Islam dan Perannya Terhadap Pendidikan Islam di Indonesia." Jurnal Ta'dib 18, no. 01 (2013): 56-84.

Crothers, Charles. "Merton as a General Theorist: Structures, Choices, Mechanisms, and Consequences." Springer 35, no. 3 (2004).

DiAngelo, Robin. "Socialization." Counterpoints 467 (2016).

Federspiel, Howard M. Islam and Ideology in the Emerging Indonesian State: The Persatuan Islam (Persis) 1923-1957. Leiden: Brill, 2001.

. The Mubammadijab: A Study of an Orthodox Islamic Movement in Indonesia. Indonesia. New York: Southeast Asia Program Publications at Cornell
University, 1970.

Feener, R. Michael. Muslim Legal Thought in Modern Indonesia. New York: Cambridge University Press, 2007.

Foster, Stephen W. "Reading Pierre Bourdieu." Cultural Anthropology 1, no. 1 (1986).

Hamid, Hamdani. "Persatuan Islam dan Usaha Berpijak di Bumi Indonesia: Perubahan Kurikulum dalam Pendidikan Pesantren." UIN Syarief Hidayatullah Jakarta, 1989.

Hefner, Robert W. "Islam and Ideology in the Emerging Indonesian State: The Persatuan Islam (PERSIS), 1923-1957 by Howard M. Federspiel." The Journal of Asian Studies 62, no. 1 (2003).

Hidayatullah, Ahmd Syarif. "Eksistensi Islam Kultural di Tengah Gempuran Gerakan Islam Transnasional." Jurnal Ilmu Agama 19, no. 1 (2018): 38-75.

Jasso, Guillermina. "Some of Robert K. Merton's Contributions to Justice Theory." Sociological Theory 18, no. 2 (2000).

Jaworski, Gary Dean. "Robert K. Merton's Extension of Simmel's Ubersehbar." Sociological Theory 8, no. 1 (1990).

Kahin, Audrey R. Islam, Nationalism and Democracy: A Political Biography of Mohammad Natsir. Singapore: NUS press, 2012.

Malasevic, Sinisa. The Sociology of Ethnicity. India: Sage Publications, 2004.

Manis, Jerome C., Bernard N. Meltzer, and Jerome G. Manis. "Blumer and Merton: Social Roles and Sociological Theories." Sociological Focus 7, no. 4 (1974).

Minhaji, Akh. "Islamic Reform in Contest: Ahmad Hassan and His Traditionalist Opponents." Studia Islamika 7, no. 2 (2000).

Mu'ammar, M. Arfan. "Pesantren dan Islam Puritan:Pelembagaan Tajdid Keagamaan di Lembaga Pendidikan Islam." Jurnal Peradaban Islam 11, no. 2 (2015): 273-90.

Muchtar, Abdul Latief. Gerakan Kembali ke Islam: Warisan Terakbir K.H A. Latief Mucbtar. Bandung: Remaja Rosdakarya, 1998.

Müller, Tim S., Peter Schmidt, and Nan Dirk 
De Graaf. "Which Societies Provide a Strong Religious Socialization Context? Explanations Beyond the Effects of National Religiosity." Journal for the Scientific Study of Religion 53, no. 4 (2014).

Nur, Muhammad. "Problem Terminologi Moderat dan Puritan dalam Pemikiran Khaled Abou El-Fadl." Kalimab: Jurnal Studi Agama dan Pemikiran Islam Problem 11, no. 1 (2013).

O’Shaughnessy, Thomas J. "Indonesian Islamic Reform. Review Islam and Ideology in the Emerging Indonesian State; The Persatuan Islam (PERSIS), 1923 to 1957 by Howard M. Federspiel." Philippine Studies 19, no. 4 (1971).

Page, Charles H. "Bureaucracy and Higher Education." The Journal of General Education 5, no. 2 (1951).

Persatuan Islam. "Sejarah Persatuan Islam." Accessed September 10, 2020. https://www.persis.or.id/page/sejarah.

Pusat, Pimpinan. Pimpinan Pusat Persatuan Islam. Qanun Asasi Qanun Dakbili. Bandung: Pimpinan Pusat Persatuan Islam (Persis), 2015.

Ridwan Nurrohman, Muhamad. "Pemikiran Hadis di Nusantara; Antara Tekstualitas dan Kontekstualitas Pemikiran Hadis Ahmad Hassan." Diroyab: Jurnal Ilmu Hadis 2, no. 1 (2017).

Rokhmadi. "Rekonstruksi Ijtihad dalam Ilmu Usul Al-Fiqh." Jurnal Pemikiran Hukum Islam 22, no. 2 (2012): 161-76.

Shodiq, M. "Pesantren dan Perubahan Sosial." Falasifa 2, no. 2 (2011).
Stoley, Kathy S. The Basic of Sociology. Westport: Greenwood press, 2005.

Suharto, Toto. Organic Community-Based Education Pesantren Persatuan Islam 19831997. Surakarta: Fataba Press, 2015.

Sztompka, Piotr. Robert K. Merton: Intellectual Profile. London: MacMillan Education, 1986.

Vandenberghe, Frédéric. "The Real Is Relational': An Epistemological Analysis of Pierre Bourdieu's GenerativeStructuralism." Sociological Theory 17, no. 1 (1999).

Wawancara

Azkia Wafiatul Wijdaniah (Bidgar SDMO PD. IPPi Kab. Garut), Wawancara, 22 Maret 2017.

Daden Robi Rahman (Ketua PD. Pemuda Persis Kab. Garut), Wawancara, 16 Maret 2017.

Dede Sodikin (Penasehat PD. Persis Kab. Garut), Wawancara, 23 Maret 2017

Ena Sumpena (Ketua Persis Kab, Garut), Wawancara, 29 Maret 2017.

Ena Sumpena (Ketua Persis Kab, Garut), Wawancara, 13 Januari 2020.

Endut Saefudin (Penasehat PD. Persis Kab. Garut), Wawancara, 23 Maret 2017.

Gungun Abdul Basith (Dosen STAI-Persis Garut), Wawancara, 28 Maret 2017.

Iyep Komarudin (Mantan Ketua PD Persis Kab. Garut dan Ketua Bidgar Haji), Wawancara, 22 Maret 2017. 